Review

\title{
Etiology of Acute Leukemia. A Review
}

\author{
Cameron K. Tebbi *
}

Children's Cancer Research Group laboratory, 13719 North Nebraska Avenue, Tampa, Florida 33613, USA

\begin{abstract}
Acute leukemias constitute some of the most common malignant disorders. Despite significant progress made in the treatment of these disorders, their etiology remains unknown. A large and diverse group of genetic and environmental variables have been proposed. The role of a variety of factors, including pre-existing and acquired genetic mutations, exposure to radiation and various chemicals during pre-conception, pregnancy and throughout life have been explored. The effects of inherited genetic variations and disorders, pre-existing diseases, infectious agents, hobbies, occupations, prior treatments and a host of other factors have been proposed, but none is universally applicable to all cases. Variation in the incidence and prognosis based on the age, sex, race, type of the disease, geographic area of residence and other factors are intriguing, but remains unexplained. Advances in genomic profiling, including genome-wide gene expression, DNA copy number, and single nucleotide polymorphism [SNP] genotype may shed some light on the role of genetics in these disparities. Separate two-hit hypothesis for the development of acute myeloblastic and lymphoblastic leukemia have been proposed. The latter combines genetics and infection factors resulting in leukemogenesis. A number of pre- and post-natal environmental conditions and exposure to infections, including a mycovirus infected Aspergillus flavus, have been suggested. The exact nature, timing, sequence of the events and mechanisms resulting in occurrence of leukemia requires further investigations. This review summarizes some of the above factors and the direction for future research on the etiology of acute leukemias.
\end{abstract}

Keywords: etiology; leukemia; acute lymphoblastic leukemia; acute myeloblastic leukemia; genetics; causes; occupations; hobbies; genetic; infections; mycovirus; aspergillus

\section{Background}

Leukemia is one of the most common malignant disorders affecting the world population. Globally, in 2018 leukemia ranked as the fifteenth most common diagnosed cancer with 437,033 cases and 309,006 mortality, amounting to the eleventh cause of death due to malignant disorders [1]. The geographic distribution of leukemia is universal with higher prevalence and mortality in the more developed countries. Based on the Cancer Facts and Figures provided by the American Cancer Society, for the year 2020, It was estimated that 178,520 individuals were to be diagnosed with leukemia, lymphoma and myeloma in the United States. This accounts for 9.9 percent of the estimated 1,806,590 new cancer cases diagnosed in that year. While both sexes are affected, leukemia is more prevalent in males. The age-standardized incidence rates for leukemia in males and females in 2018 in the United States were 6.1 and 4.3 per 100,000, respectively. Likewise, the mortality rate of 4.2 per 100,000 population was higher for males compared to 2.8 per 100,000 in females [1]. 


\section{Age and Race}

Age and race are important factors in the incidence of leukemias. For example, in the United Kingdom, 42.8\% of all leukemias occur in the individuals over 65 years [2]. A review of the subject in the United States reports that the overall age-adjusted leukemia incidence is highest in White population at 15 per 100,000, followed by Blacks at 11 per 100,000 , and Hispanics 10.6 per 100,000 population [3]. In this report, the incidence among Asian/Pacific Islanders was 7.8 per 100,000 and in American Indian/Alaskan Natives, 8.3 per 100,000 population [3]. Similar racial and ethnic patterns were found for age-adjusted mortality rates per 100,000 population, which were 7 for White population, 5.6 for Blacks, 4.8 in Hispanics, 3.8 in Asian/Pacific Islanders and 3.3 in Indian/Alaskan Natives [3].

While leukemia affects all age groups, its distribution varies based on the type of the disease. The age-adjusted incidence rate of leukemia from 2012-2016 In the United States in children, adolescents and young adults younger than 20 years was estimated to be approximately 4.6 per 100,000 . Approximately 4.8 percent of all leukemia and lymphoma cases were diagnosed in individuals younger than 20 years of age. As such, it constituted approximately $20-30 \%$ of all cancers in this age group. Acute lymphoblastic leukemia (ALL), which is most common in childhood and adolescents, accounts for approximately $75 \%$ of all leukemia cases in the individuals under 20 years of age and approximately one quarter of all pediatric cancers. The peak incidence is in children ages 2-5 years. On the contrary, acute myeloblastic leukemia (AML), with the overall incidence of 3-5 cases per 100,000 in general population, is far more prevalent in adults, with an incidence of only 7.7 per million between the ages of 0-14 years. Indeed, the median age at diagnosis for AML is 66 years with $54 \%$ of patients being diagnosed after age 65 and 33\% over age 75 years. It is of note that the incidence of acute lymphoblastic leukemia has increased over time, at least in the pediatric age group. This, in part, has been attributed to the improved accuracy of the diagnostic techniques and reporting. The incidence for AML appears to have been unchanged [4].

As noted above, racial differences in the incidence of, and mortality caused by different types of acute leukemias have been reported. The incidence for some leukemias, such as ALL, is higher in White than Black population. Based on a 2011 report by the American Association for Cancer Research, Hispanic children have the highest incidence of ALL and one of the lowest survival rates among pediatric patients diagnosed in the United States. In this regard, the report indicates that the overall mortality risk for ALL is 45 and 46 percent greater for Blacks and Hispanics than the White population, respectively. The rate of increase death in AML was 12 and 6 percent higher in these two groups than in the White population [5].

Despite documented racial and ethnic differences in the incidence and outcome, the underlying causes for this disparity remains poorly understood [6-10]. While the role of the financial, social structure versus genetic factors in the incidence and outcome in various populations have been considered, the underlying causes are poorly recognized. Advances in genomic profiling, including genome-wide gene expression, DNA copy number, and single nucleotide polymorphism [SNP] genotype may shed some light regarding the roles of genetic in these disparities [11].

\section{Genetics}

Undoubtedly, genetic plays a major role in the etiology of leukemia. This is most evident in identical twins. If one of the identical twins develops the disease before the age of 7 years, the other has twice as much chance of developing this disease than the general population. The chance of developing leukemia then reduces in time. The twin who reaches age 15 years without developing leukemia, appears not to have higher risk of developing this disease than the average population $[12,13]$. 
While for the majority of leukemia cases there are no obvious known predisposing factor, some genetic and acquired germline mutations and clonal chromosomal abnormalities are associated with increased incidence of leukemia [14]. Increasingly, using genome wide association studies, germline mutations which can cause leukemia prone changes have been identified. Patients with DNA repair disorders and constitutional chromosomal anomalies can be predisposed to developing leukemia. Some inherited mutations have potential to increase the risk of developing leukemia, this in absence of extramedullary phenotypes. Some families have an increased incidence of leukemia with no known inherited mutations [14]. Major inherited and genetic disorders resulting to predisposition to acute leukemia are summarized in Table 1. Identified genes that can be inherited in an autosomal dominant fashion and potentially result in the development of leukemia include CEPBA, RUNX1 and GATA2. The CEBPA, located at chromosome19q13.1, encodes granulocytic differentiation factor $\mathrm{C} / \mathrm{EBPa}$, a member of bZIP family of proteins. RUNX1 gene is located at 21q22.12 and is a transcription factor involved in hemopoiesis. GATA2 gene is located on 3q21.3 and is involved in preserving integrity of hematopoietic stem cells and regulation of phagocytosis. Mutation of GATA2 has been associated with congenital neutropenia and MonoMAC syndrome, a disorder which frequently results in myelodysplastic syndrome (MDS), increased rate of infections and AML or chronic myelomonocytic leukemia [14]. Monosomy 7 has been reported in families with multiple members having MDS and AML. Likewise, inherited bone marrow failure syndromes with a variety of genetic abnormalities can lead to the development of leukemia [14].

Individuals with certain genetic disorders are known to have increased rate of developing leukemia [14-22]. Disorders such as Down syndrome, Ataxia-telangiectasia, Bloom syndrome, Klinefelter syndrome and Diamond Blackfan anemia are at higher risk for leukemia [14-22]. Point, missense or nonsense mutations can occur in the tumor suppressor genes, some of which encode for proteins with suppressive effects on regulation of cell cycle and ability to promote apoptosis. Disorders such as Li-Fraumeni syndrome, neurofibromatosis 1, Noonan syndrome and CBL syndrome are associated with high risk of leukemia [14] . Bone marrow failure syndromes such as Thrombocytopenia with absent radius, Shwachman-Diamond syndrome, amegakaryocytic thrombocytopenia, dyskeratosis congenita and severe congenital neutropenia including Kostmann syndrome are also associated with higher risk for the development of leukemia [14]. Myelodysplastic syndrome, myelodysplasia, polycythemia vera, primary thrombocythemia are also found to be associated with the increased rate of this disease [14]. DNA repair defects such as mismatch repair deficiency syndrome which involves sporadic mutations in genes responsible for DNA repair, as seen in some variants of Lynch syndrome, ataxia telangiectasia, Nijmegen breakage syndrome, Bloom syndrome and Fanconi anemia, can be associated with hematological malignancies [14,19]. It is of note that approximately $33 \%$ of patients with Fanconi anemia develop a hematological malignancy by age 40. Germline polymorphisms in IKZF1, CDKN2A, CEPBE and ARID5B have been shown to be associated with increased risk of ALL [14].

Patients with various primary inherited immunodeficiency syndromes are predisposed to the development of malignant disorders including leukemia [14]. These include Wiskott-Aldrich syndrome, a X-linked disorder with the triad of thrombocytopenia, immune deficiency and eczema and Bruton agammaglobulinemia which is due to Bruton tyrosine kinase gene located at chromosome Xq21.3-22 location.

As is discussed in the AML and ALL sections of this review, two-hit theories involving genetics for the development of leukemias have been proposed. 
Table 1. Inherited predisposing syndromes to hematologic malignancy

\begin{tabular}{|c|c|c|c|}
\hline Predisposing disorder & Gene & Inheritance & Type of leukemia \\
\hline CEBPA & CEBPA & $\mathrm{AD}$ & MDS/AML \\
\hline Monosomy 7 & $7 p / q$ & $\mathrm{AD}$ & MDS/AML/ALL \\
\hline Familial platelet disorder/AML & $R U N X 1$ & $\mathrm{AD}$ & $\begin{array}{l}\text { MDS/AML/T-cell } \\
\text { ALL }\end{array}$ \\
\hline MonoMAC Syndrome & GATA2 & $\mathrm{AD}$ & MDS/AML \\
\hline Familial AML with mutated DDX41 & $D D X 41$ & $\mathrm{AD}$ & MDS/AML/CMML \\
\hline Thrombocytopenia 2 & ANKRD26 & $\mathrm{AD}$ & MDS/AML \\
\hline Thrombocytopenia 5 & ETV6 & $\mathrm{AD}$ & $\begin{array}{l}\text { MDS/AM/CMML, } \\
\text { B-cell ALL }\end{array}$ \\
\hline $\begin{array}{l}\text { Familial MDS/AML with mutated } \\
\text { GATA2 }\end{array}$ & GATA2 & $\mathrm{AD}$ & MDS/AML/CMML \\
\hline Li-Fraumeni syndrome & TP53 & $\mathrm{AD}$ & ALL \\
\hline Neurofibromatosis type 1 & $N F 1$ & $\mathrm{AD}$ & JMML/MDS/AML \\
\hline Noonan syndrome & PTPN11 & $\mathrm{AD}$ & JMML/MDS/AML \\
\hline CBL syndrome & $C B L$ & $\mathrm{AD}$ & JMML \\
\hline $\begin{array}{l}\text { Familial aplastic anemia with mutated } \\
\text { SRP72 }\end{array}$ & $S R P 72$ & $\mathrm{AD}$ & MDS \\
\hline $\begin{array}{l}\text { Familial B- cell ALL with mutated } \\
\text { PAX5 }\end{array}$ & $P A X 5$ & $\mathrm{AD}$ & ALL \\
\hline Germline SH2B3 & $\mathrm{SH} 2 \mathrm{~B} 3$ & $\mathrm{AR}$ & ALL \\
\hline $\begin{array}{l}\text { Telomere syndromes (dyskeratosis } \\
\text { congenita) }\end{array}$ & $\begin{array}{l}\text { TERC, TERT, CTC1, DKC1, NHP2, } \\
\text { NOP10, RTEL1, TINF2, WRAP53, } \\
\text { ACD, PARN }\end{array}$ & $\mathrm{AD}, \mathrm{AR}$ & MDS/AML \\
\hline Diamond Blackfan anemia & RPS19, RPL5, RPL11 & Sporadic, AD, AR, & MDS/AML/ALL \\
\hline Shwachman-Diamond syndrome & SBDS & $\mathrm{AR}$ & MDS/AML/ ALL \\
\hline Amegakaryocytic thrombocytopenia & $c-M P L$ & $\mathrm{AR}$ & MDS/AML \\
\hline $\begin{array}{l}\text { Thrombocytopenia with absent radii } \\
\text { syndrome }\end{array}$ & $R B M 8 A$ & AR, Sporadic & ALL/AML \\
\hline Severe congenital neutropenia & ELA2, HAX1, G6PC3, WASP & $\mathrm{AD}, \mathrm{AR}, \mathrm{X}$-linked & MDS/AML \\
\hline Fanconi anemia & $\begin{array}{l}\text { FANCA, FANCB, FANCC, BRCA2, } \\
\text { FANCD2, FANCE, FANCF, FANCG, } \\
\text { FANCI, BRIP1, FANCL, FANCM, } \\
\text { PALB2, RAD51C, SLX4 }\end{array}$ & $\overline{\mathrm{AR}}$ & ALL/AML \\
\hline Mismatch repair Cancer syndrome & PMS2, MSH6, MLH1, MSH2 & $\mathrm{AR}$ & ALL \\
\hline Ataxia telangiectasia & ATM & $\mathrm{AR}$ & ALL \\
\hline Nijmegen breakage syndrome & $N B S 1$ & $\mathrm{AR}$ & ALL \\
\hline Bloom Syndrome & $B L M$ & $\mathrm{AR}$ & ALL \\
\hline Werner Syndrome & $W R N(R E C Q L 2)$ & $\mathrm{AR}$ & MDS/AML \\
\hline Rothmund-Thomson & RECQL4 & $\mathrm{AR}$ & AML \\
\hline Wiskott-Aldrich Syndrome & WASP & X-linked & ALL \\
\hline Burton's agammaglobulinemia & $B T K$ & X-linked & ALL \\
\hline Trisomy 21 (Down Syndrome) & $21 q$ & Sporadic & ALL/AML \\
\hline
\end{tabular}

$\mathrm{AD}=$ autosomal dominant, $\mathrm{AR}=$ autosomal recessive, $\mathrm{MDS}=$ myelodysplastic syndrome, $\mathrm{ALL}=$ acute lymphoblastic leukemia,

$\mathrm{AML}=$ acute myeloblastic leukemia, JMML=juvenile myelo-monocytic leukemia, $\mathrm{CMML}=$ chronic myelomonocytic leukemia. 
A large number of environmental causes for the development of leukemia have been suggested. These mostly involves exposure to cancer-causing agents, including chemicals, infectious agents and radiation during various stages of life [23-32]. Certain exposures, occupations, industrial hazards, and hobbies have been implicated in a higher risk of leukemia [29-32] (Table 2). Occupations described to be associated with increased risk for leukemias include, but are not limited to, agricultural and forestry work and crop production [33-40] with exposure to pesticides and fertilizers [41-43], construction [33], animal slaughtering and poultry work $[33,44,45]$, vocations in the oil/gas industries with exposure to benzene [35,43,46-52], oil refining and petrochemicals [53-59], automobile mechanic works [37,60], electrical utility careers, jobs with exposure to magnetic fields [6166], works in the nuclear power industry/exposures to ionizing radiation [50,51,67-71], furniture manufacturing and repair [72] and nursing and health care positions with exposures to infectious agents/viruses [37,39,73-75]. Other occupations with increased risk of leukemia include hairdressing and hair dying [50,76], Painting [77-80], Laundry work, dry cleaning with exposure to dry cleaning chemicals $[37,81,82]$, teachers [35,37], workers in shoe and boot manufacturing industry, [83], taxi, bus, truck, railway drivers and conductors $[50,53,66,84,85]$. Occupations with exposure to alkylating agents and formaldehyde $[73,86,87]$, textile workers and manufacturers [50,88], semiconductor workers etc. [50,89] are also found to have higher risk of leukemia. With a few exceptions, such a diverse range of occupations, without a unifying element, lack specificity.

Direct and indirect exposures to chemical and pesticides, in a variety of occupations, as a cause for the development of leukemia has been suggested [91-93]. Contact with hydrocarbons compounds such as benzene, gasoline and trichloroethylene has been implicated in the development of leukemia $[59,94]$. Likewise, in children, a multiplicity of factors including parental occupations, has been proposed to increase risk of acute leukemia. A review of the subject is available [90].

\section{Effects of Radiation}

The effects of Ionizing radiation in the development of leukemia at various phases of life, including preconception, in utero, and postnatal exposures has been proposed and various examples have been published. A correlation between the dose of irradiation and occurrence of leukemia has been reported [95,96]. Following the bombing of Hiroshima and Nagasaki, Japan, the rate of occurrence of leukemia among survivors who were within $1000 \mathrm{~m}$ of the explosions was 20-fold higher than the general population [96]. More recently, consequences of Chernobyl nuclear power plant accident have been studied [9799].

There are conflicting data regarding the risk of the development of leukemia and exposure to diagnostic x-rays (100-103). Some studies have shown an increased risk for childhood leukemia related to paternal diagnostic x-rays. An increased risk was found if two or more $X$ rays of the lower abdomen were done. However, no increased risk was noted if the data were restricted to lower abdominal $X$ rays $[100,101]$. In one study, no increased risk of leukemia was noted with maternal abdominal x-rays. Some evidence of increased risk in offspring was noted if the father had more than one abdominal x-ray done before conception or had a prior intravenous pyelogram [103]. some reports reveal only a slight elevation in risk, but no evidence of a dose-response relationship, when $\mathrm{x}$ ray procedures near the time of diagnosis are excluded. In general, correlation between diagnostic X-rays and development of leukemia is inconsistent, inconclusive and subject to a number of variables, including time and reason for the procedure and statistical errors. Some studies have reported increased rate of leukemia in individuals who have had diagnostic X-ray. For example, in one study, children having one or more computed tomography scans had an increased ratio of developing leukemia, indicating that even with low doses of ionizing radiation there is an increased risk of this disease [104]. 
However, others find no correlations between diagnostic X-ray tests and increased risk, especially if tests done close to the time of diagnosis of leukemia are subtracted[103].

Inconsistent results regarding exposure to nonionizing radiation as an etiological factor for the development of leukemia have been reported, and generally the effects of such an exposure in the development of this disease has been disputed [105-110].

\section{Table 2.}

\section{Industries with increased rate of acute leukemia}

Agriculture/Crop production and related ventures

\section{Forestry}

Fishing and hunting

Construction and related services

bAnimal slaughtering/poultry processing

oil refining and petrochemicals

\section{Industries with decreased rate of acute leukemia}

Professional, legal and technical services

Computer system and related services

Business support, management and administrative services

Public administration 


\section{Table 3.}

\section{Occupations associated with increased risk of acute leukemia}

Farmers, foresters, agriculture workers and related occupations

Fishing and related works

Construction, painting, maintenance and related occupations

Carpet, tile and floor installers

Building and ground cleaning, janitorial and maintenance workers

Healthcare workers

Workers exposed to solvents, chemicals and benzene

Electricians/electrical utility workers

Workers exposed to high doses of radiation/ nuclear power industry

Automobile mechanics /drivers/rail conductors and pilots

Furniture manufacturers and repair personnel

Laundry workers, dry cleaners

Textile workers and manufacturers

Hairdressers

Teachers

\section{Occupations associated with decreased risk of acute leukemia}

Attorneys and legal workers

Moving

\section{Prior Immunosuppressive and Chemotherapy}

Individuals who have received chemotherapy for the treatment of cancer, with or without radiation, have an increased risk of leukemia. A variety of immunosuppressive therapies can also increase risk of developing acute leukemias. Certain chemotherapy agents such as alkylating agents, platinum derivates and topoisomerase II inhibitors are associated with higher risk for the development of this disease. Addition of radiation therapy to the chemotherapy increase the risk involved [111,112]. In a study of 82,700 women with invasive breast cancer, the risk of acute nonlymphocytic leukemia was significantly higher after regional radiotherapy alone, alkylating agents alone, and combination of chemotherapy and radiation. The relative risk was 2.4 for radiotherapy, 10 for alkylating 
agents and 17.4 for the combination. The observed risk for the development of leukemia was dose and treatment dependent, with melphalan having ten times more leukemogenic effect than cyclophosphamide. With total cyclophosphamide doses of less than 20,000 mg, only small increase in risk of secondary leukemia was observed [113].

\section{Parental and residential factors}

In the pediatric age group, paternal hobbies and occupations such as work involving contact with gasoline, paint, pigments, solvents, pesticide and plastics, jobs in metal, textile, pharmaceutical industries and professions requiring engine repair, have been investigated for the development of leukemia in children. Direct and indirect effects of chemical agents on children, including via breast feeding, exposure to contaminated clothing or environment have been implicated [59,91-93,107,113-119]. Likewise, household exposure to insecticides has been found to be associated with higher risk of leukemia in the pediatric age group [120]. Proximity of place of birth and industrial sites with release of volatile organic compounds has been reported [121].

Parental alcohol consumption and smoking during prenatal and neonatal periods and childhood have been suggested to contribute to the development of leukemia in their offspring. The risk may be related to the severity, frequency, duration and extent of the exposure [122-129]. Maternal use of marijuana during and after pregnancy has been reported to increase risk of ALL and AML by 10 folds [130]. Effects of the Chemico-Biological Interactions have been explored.

Several studies regarding the etiology of leukemia in childhood have examined the relation of the parent's age, maternal history of fetal loss, birth characteristics and higher birth weight. A positive trend associating maternal and paternal age greater than 35 and 40, respectively, and the occurrence of ALL in the offspring was found. Maternal and paternal age exceeding 40 years has been reported to be associated with an increased odd ratio of 1.95 and 1.45 for the development of childhood leukemia [131]. Maternal history of fetal loss and the risk of the development of ALL and AML is conflicting. This may reflect genetic predisposition or the effects of the environment [132-134]. Higher birth weight is presumed to reflect increased ability for cell proliferation [135].

\section{Infections}

Infections, including bacterial, viral and fungal agents alone, and in conjunction with genetic mutations, have been implied in leukemogenesis. Infections have been suspected and reported to be associated with the development of cancer in general, and acute leukemias in particular, save for some recent reports, generally an assumption without availability of a consistent agent [136-139]. The impact of a variety of infectious organisms including Epstein-Barr virus, herpesvirus, human immunodeficiency virus (HIV), SARS, COVD-19, Human T-lymphotropic virus (HTLV-1) and others in the development of leukemia in certain patients have been hypothesized and explored [90,136,140-150]. Associations, such as that of EBV and Burkett's lymphoma in the endemic area of Eastern Africa is well known. Despite existence of a relatively strong association, lack of universal application of the finding, characteristic 8;14 chromosomal translocation resulting in constitutive activation of c-Myc oncogene, variation in viral gene expression in subgroups of patients, effects of EBV oncoproteins, p53 mutations and a number of other factors complicate this connection. Exposure to EBV in the first two years of life, resulting in serological response, and the development of Burkett's lymphoma has been reported [136,146,151].

Human T-cell leukemia virus type I, also known as human T-lymphotropic virus (HTLV-1) has been linked to adult T-cell leukemia/lymphoma (ATL), presumably by insertion of their DNA or RNA into the host cell. HTLV-I is proposed to cause ATL in approximately $5 \%$ of carriers after a long latent period. Post infection, it is proposed that HTLVI promotes the clonal proliferation of HTLV-I infected cells in vivo by actions of encoded 
viral proteins, including Tax [152]. Mice with monoallelic loss of the B-cell transcription factor PAX5, are genetically predisposed to B-cell ALL, if exposed to pathogens [144,153].

Carcinogenic effects of fungal agents and aflatoxin are well established, but the mechanisms resulting in this phenomenon are not entirely clear. Few reports of fungal isolation from residences of patients with leukemias, including ALL, are available [154-157] and generally, their carcinogenic impacts are attributed to immunosuppression $[155,156]$. Mycotoxin-producing fungi from a residence associated with four patients with leukemia from three families has been reported and the leukemogenesis attributed to the immune depressive effects of mycotoxins [155]. Study of fungal agents isolated from a house where a husband and wife had developed acute myelomonocytic and undifferentiated leukemia, respectively, have been reported. The extract of the fungal isolates was found to have a depressive effect on phytohemagglutinin skin test in guinea pigs as compared to control [156]. In a published article, sera from 36 patients with cancer, 15 of whom had leukemia or lymphoid malignancy, using a modified microimmunodiffiusion technique, supernatant of the culture of Aspergillus had produced 30\% precipitation in cancer patients and only $6 \%$ in controls. This effect was attributed to reaction to the aflatoxin produced by the fungi [155].

In recent reports, a Aspergillus Flavus species, isolated from the home of a patient with ALL, by electron microscopy examination was found to contain mycovirus within the body of the organism and its culture supernatant $[138,139]$. In chemical analysis, this organism was found not to produce any aflatoxin. The latter was attributed to the known fact that fungi, as virus hosts, provide a unique platform for virus/virus and virus/host interactions that can block the production of aflatoxin [158-160]. Using culture of this mycovirus containing Aspergillus flavus with ELISA technique, plasma of patients with ALL in full remission and long-term survivors were found to have antibody to this organism. By this test, it was found possible to distinguish patients with ALL in remission from normal controls as well as those with sickle cell disease and solid tumors [138]. In a related study, exposure of peripheral blood mononuclear cells (PMBC) from patients with ALL in complete remission to the products of the culture of the above mycovirus containing Aspergillus flavus had reproduced cell surface phenotypes and genetic markers characteristic of ALL. Controls were found to be negative. Serial timeline evaluation of the cell surface phenotypes, using flow cytometry, had revealed that the reported conversion from normal to leukemic cell surface markers had started shortly after incubation with the supernatant of the mycovirus containing Aspergillus Flavus and completed in 24 hours. Addition of EBV to the mixture had not change the results. In the experiments described, aflatoxin, used as a positive control, had indiscriminately induced abnormal cell surface phenotypes in both, PBMC from normal controls and ALL patients in remission. This study may indicate that mycovirus containing Aspergillus Flavus has a direct effect on ALL cells in remission and is well capable of altering and transforming cellular and genetic makeup of the genetically vulnerable cells. The report also indicates that in limited studies, when cultures with and without EBV were irradiated, this significantly had increased co-expression of CD10/CD19, which is one of the characteristic cell surface phenotypes in the ALL [139]. Considering the two-hit theory for the development of acute lymphoblastic leukemia, it is postulated that the mycovirus containing Aspergillus Flavus may provide a consistent organism in the mechanism of leukemogenesis in acute lymphoblastic leukemia [138].

These experiments may give credence to the idea that a combination of genetics and epigenetic and environmental factors have a role in the development of leukemias [139].

Mycotoxins produced by fungal agents, including aflatoxins, ochratoxin A, fumonisins, certain trichothecenes, and zearalenone, are known to be carcinogenic [161]. Some mycotoxins, such as Patulin and Gliotoxin, a toxic epipolythiodioxopiperazine metabolite with significant immunosuppressive activity, are capable of causing apoptosis in 
PBMC and have selective in vitro cytotoxicity, while others have suppressive effects on the immune response [162,163]. Gliotoxin, in vivo, is reported to inhibit transcription of $\mathrm{NF}-\varkappa \mathrm{B}$ in response to a variety of stimuli in $\mathrm{T}$ and $\mathrm{B}$ cells. In high concentrations, this agent was reported to prevent NF- $\varkappa$ B DNA binding in vitro [164]. Presence of NF- $\varkappa \mathrm{B}$ p65 (Rel A) is required for protection from TNA- $\alpha$. It is of interest that constitutively activated NF- $\chi \mathrm{B}$ complexes have been previously reported in the majority (39/42) of ALL patients without subtype restriction [165].

The correlation between exposure to infections, including fungal organism, and occupations with increased rate of leukemia, such as agricultural work, which potentially exposes the individuals to fungal and other agents is not clear and require future investigation.

As noted before, in recent years, two-hit hypothesis, indicating multi factorial causation for the development of acute leukemias have been proposed [166,167]. The specifics for two major acute forms of the disease, i.e., acute lymphoblastic and myeloblastic leukemia are described in the following sections.

\section{Acute Myeloblastic Leukemia}

Acute myeloblastic leukemia (AML) has two peaks in occurrence, early childhood and later in adults. The median age for the newly diagnosed patients with AML is 66 years. While the disease can occur at any age, the diagnosis is relatively rare before 40 years of age. Based on the US statistics obtained from 2000 to 2004 , the incidence in individuals under the age 65 is 1.7 per 100000, with the rate increasing to 16.8 per 100,000 in those ages 65 or older. The incidence of AML varies with gender and race. Overall, in the SEER data base for children aged 1-4 years there is an incidence rate of 0.9 per 100,000 for boys and 0.8 for girls [168].

In the first few years of life, the incidence of AML in Whites is three-fold higher than in blacks; however, black children after this age have slightly higher rates of this disease. In the US between 2000 and 2004, with the rate of 3.7 per 100,000 population, AML was more common in Whites than Blacks who had a rate of 3.2 per 100,000 [168]. The increased incidence with age is partially suspected to be due to the progression of myelodysplastic syndromes (MDS) to AML. The so called MDS-related AML is characterized by common cytogenetic abnormalities shared with MDS and has a higher frequency of unfavorable prognosis. In children, the incidence of acute myeloblastic leukemia during 2005-2009 was estimated to be 7.7 cases per million for ages $0-14$ years. In this age group, the peak incidence rate occurs in the first year of life and then decreases steadily up to the age of 4 years. In infants less than one year of age the incidence is 18.4 per million [2,169]. The incidence of AML has remained relatively constant in children and adults with the exception of slight increase in the oldest age group [170].

Other than MDS, etiology for most cases of AML is unclear. A growing knowledge concerning leukemogenenic agents, specially chemotherapy regimens used for the treatment of a variety of malignant disorders, have been recognized [111,112]. Associations of certain molecular pathogenesis such as $(8 ; 21)$ translocation and inversion of chromosome 16 in AML have been reported. In addition to these genetic alterations, epigenetic changes such as promoter silencing by hypermethylation of the p15/INK4b and other genes in the pathogenesis of AML, have been recognized. The association of certain genetic factors, including genetic defects and AML, especially in children, is suggested. As noted above, patients with a variety of genetic disorders such as Down's syndrome, have substantially higher potential for the development of malignant disorders, including AML. For example, children with Trisomy 21 have a 10- to 20-fold increased potential of developing acute leukemia, mostly AML [10,14,16,21,171,172].

Acquired genetic and clonal chromosomal abnormalities are found in $50-80 \%$ of AML patients, especially in older individuals and those with secondary leukemia. These 
abnormalities include loss or deletion of chromosome 5, 7, Y, and 9. Chromosome translocations, including those of $\mathrm{t}(8 ; 21)$ (q22;q22); t(15;17) (q22;q11), trisomy 8 and 21, and abnormalities in the chromosomes 16, 9, and 11 have been reported [2,173-181]. Cases of tetraploid acute leukemia have been documented. In one case report, a pseudodiploid clone characterized by $\mathrm{t}(8 ; 21)$ and a hypotetraploid clone with two $\mathrm{t}(8 ; 21)$ and a loss of two $\mathrm{Y}$ chromosomes was documented [182].Specific associations of the most frequent balanced translocations in AML, such as AML with the $(8 ; 21)$ translocation and inversion of chromosome 16 , and acute promyelocytic leukemia with the $(15 ; 17)$ translocation have been reported. In addition to these genetic alterations, epigenetic lesions such as promoter silencing by hypermethylation of the p15/INK4b and other genes, in the pathogenesis of AML have been recorded.

A "two-hit-hypothesis" for the development of AML phenotype by class I and II mutations has been proposed. This two-hit hypothesis is different from that proposed for ALL. Among candidates for class I are mutations in FLT3, N-RAS or K-RAS. Class II mutations are exemplified by AML1/ETO, CBF/ SMMHC, PML/RAR, and MLL-related fusion genes. An example for this hypothesis is activating mutations in FLT3, which is seen in all subtypes of AML and can confer a proliferative advantage to the hematopoietic progenitors, (class I) and gene rearrangements affecting one of the hematopoietic transcription factors (class II). A combination of class I and class II mutations are necessary for the proposed theory to result in the development of AML [166,183]. This theory is in line with increased rate in the development of AML in individuals treated for other malignant disorders [111,112].

Risk factors for the development of AML, as outlined before, include exposure to radiation, chemicals and engagement in various occupations and hobbies.

In some forms of acute promyelocytic leukemia (APML), a distinct chromosomal and gene-rearrangement aberrations have been recognized. These may be different in various areas of the world. For example, while increased incidence of APML in adult patients originating from Latin America and in children in Southern Europe has been reported, genetic rearrangement in these two localities are different. This may indicate that a particular breakpoint site may be responsible in various locations. It is known that certain polymorphisms in the genes metabolizing carcinogens are associated with an increased risk of AML. For example, NAD(P)H:quinone oxidoreductase 1 (NQO1), is a carcinogenmetabolizing enzyme that detoxifies quinones and reduces oxidative stress. A polymorphism at nucleotide 609 of the NQO1 complementary DNA decreases the activity of these enzymes and can result in therapy-related AML [166,184,185].

\section{Acute Lymphoblastic Leukemia}

Acute lymphoblastic leukemia (ALL) is the most common malignancy diagnosed in children, representing one quarter of all pediatric cancers. The annual incidence of acute lymphoblastic leukemia within the United States is approximately 4.6 cases per 100,000 children age 0-14 years, with a peak incidence at aged 2-5 years. During the first year of life, the incidence of ALL is slightly higher in females than males [186].

Similar to other leukemias, the role and possible effects of a number of factors, as outlined above, for the development of ALL have been proposed. The effects of various environmental factors including parental preconception, in utero and postnatal exposure to ionizing radiation have been explored. Likewise, the risks of nonionizing radiation, chemicals, infections, hydrocarbons and pesticides have been evaluated. The effects of parental alcohol, cigarette, and illicit drug use in development of ALL in offspring have been examined.

Genetics play a major role in the development of leukemia in general and acute lymphoblastic leukemia in particular. The importance of the genetics is most evident based on the concordance studies on identical twins with leukemia $[12,187,188]$. 
The concept that some cases of leukemia originate in utero by leukomogenic translocations or clonotypic gene fusion sequences is intriguing. Siblings of children with leukemia have a higher risk than others to develop this disease, albeit the risk in relatively minimal [189,190].

It is well recognized that some genetic disorders including Down syndrome $[15,16]$

Shwachman syndrome [17], neurofibromatosis [18], Fanconi anemia [19,20], Bloom syndrome [20,21], and ataxia telangiectasia [22] are associated with the increased rate of leukemia. Some of these syndromes such as Down and Bloom syndromes and Fanconi anemia have a higher incidence of AML than ALL. While genetic syndromes resulting in the development of ALL only accounts for a very small portion of the cases, the fact that they are associated with the increased rate of this disease points to the importance of genetics in the process of leukemogenesis. In B-cell ALL, genetic alterations, which are specific to each ALL immunophenotype, include hyperdiploidy, hypodiploidy, $B C R$ ABL1, ETV6-RUNX1, or TCF3-PBX1 fusions; PAX5 or ETV6 mutations, MLL rearrangements, or intrachromosomal amplification of chromosome 21 (iAMP21) specific for BALL. Alterations in LMO2, TAL1, TAL2, TLX1, TLX2, or HOXA are characteristics of Tcell ALL [183,191].

A revised taxonomy of B-ALL highlights the genetic heterogeneity of this disease by incorporating 23 subtypes, defined by chromosomal rearrangements, sequence mutations or heterogeneous genomic changes. Most of these molecular changes are acquired and not inherited [192]. Epigenetic priming in pediatric ALL has been suggested [193].

A recent two-hit theory combines genetic mutation and exposure to one or more infections for the development of ALL. The revised two-hit model for the occurrence of precursor B cell acute lymphoblastic leukemia suggests that this disease arises through a twostep process. The proposed first step is a predisposing genetic mutation. The second step involves exposure to one or more infections [167]. This proposal therefore suggests that the process of ALL development is initiated in utero by fusion gene formation or hyperdiploidy, and production of pre-leukemic clone. The step one is estimated to occur in approximately $5 \%$ of newborns, but only one in a 100 of the predisposed proceeds to develop ALL. It is postulated that exposure to infections early in life are protective. In absence of such an exposure in a small fraction of the population, later exposure to infection triggers the critical secondary cellular mutations.

In Western industrialized countries, approximately $80 \%$ of the cases of B-lineage ALL have either an ETV6/RUNX1 translocation or a high-hyperdiploid leukemic clone. These are proposed to have been initiated in utero. Only one percent of healthy newborns have translocation $\mathrm{t}(12 ; 21)[E T V 6 / R U N X 1]$-positive cord blood cells. In the industrialized countries, a lower chance of exposure to infections in early life is proposed to be reason for a relatively higher rate of ALL in children. In contrast, in the developing countries, a higher rate of exposure to infections and possibly malnutrition are proposed to contribute to a reduced rate of childhood ALL. These factors are proposed to increase the cortisol secretion during infections and the cellular response to cortisol [194].

Although the exact sequence of the events cannot be ascertained and multiple alternatives can exist, genetic predisposition with random exposure to an infection can be plausible. While a number of genetic mutations are proposed, no infectious agent or category has been suggested. Recent reports suggest a mycovirus containing Aspergillus flavus as one of the possible candidates for the infection $[138,139]$.

\section{Conclusion:}

Acute leukemias account for a significant portion of malignant disorders. These malignancies occur universally, albeit with different rates in various areas of the world and affect all age groups, including children. While association of significant causative factors for acute leukemias have been reported, the etiology of these disorders remains unclear. 
Recent advances in genetic and epigenetics provide indications for their involvement in leukemogenesis in acute leukemias. Likewise, effects of the environmental factors including infections have been explored. Recent finding of antibody to a mycovirus containing Aspergillus flavus in patients with ALL in remission and re-development of cell surface phenotypes and genetics, characteristic of ALL upon exposure on PBMN cells to the products of this organism, may provide a new venue for research in leukemogenesis. More research to fulfill the required tenants of theories regarding the development of acute leukemias based on the combining genetics and environment are needed.

Acknowledgement:_Editorial assistance of Ms. Bonnie A. Woodworth in preparation and transcription of the manuscript is sincerely appreciated.

\section{References}

1. Bray, F.; Ferlay, J.; Soerjomataram, I.; Siegel, R.L.; Torre, L.A.; Jemal, A. Global cancer statistics 2018: GLOBOCAN estimates of incidence and mortality worldwide for 36 cancers in 185 countries. CA Cancer J Clin 2018, 68, 394-424, doi:10.3322/caac.21492.

2. Deschler, B.; Lübbert, M. Acute myeloid leukemia: epidemiology and etiology. Cancer 2006, 107, 2099-2107, doi:10.1002/cncr.22233.

3. Bispo, J.A.B.; Pinheiro, P.S.; Kobetz, E.K. Epidemiology and Etiology of Leukemia and Lymphoma. Cold Spring Harbor Perspectives in Medicine 2020, 10, a034819.

4. Ries, L. SEER cancer statistics review, 1975-2002. http://seer/. cancer. gov/csr/1975_2002/ 2002.

5. American Association for Cancer Research. "Death rate higher in minorities with acute leukemia, s.f.S.S.D., 19 September 2011. < www.sciencedaily.com/releases/2011/09/110919163952.htm>.

6. Patel, M.I.; Ma, Y.; Mitchell, B.; Rhoads, K.F. How Do Differences in Treatment Impact Racial and Ethnic Disparities in Acute Myeloid Leukemia? Cancer Epidemiology Biomarkers Eamp; Prevention 2015, 24, 344-349, doi:10.1158/1055-9965.epi-140963.

7. O'Keefe, E.B.; Meltzer, J.P.; Bethea, T.N. Health disparities and cancer: racial disparities in cancer mortality in the United States, 2000-2010. Frontiers in public health 2015, 3, 51. 
8. Pollock, B.H.; DeBaun, M.R.; Camitta, B.M.; Shuster, J.J.; Ravindranath, Y.; Pullen, D.J.; Land, V.J.; Mahoney, D.H.; Lauer, S.J.; Murphy, S.B. Racial differences in the survival of childhood B-precursor acute lymphoblastic leukemia: a Pediatric Oncology Group Study. Journal of Clinical Oncology 2000, 18, 813-823.

9. Kadan-Lottick, N.S.; Ness, K.K.; Bhatia, S.; Gurney, J.G. Survival variability by race and ethnicity in childhood acute lymphoblastic leukemia. Jama 2003, 290, 2008-2014.

10. Bhatia, S.; Sather, H.N.; Heerema, N.A.; Trigg, M.E.; Gaynon, P.S.; Robison, L.L. Racial and ethnic differences in survival of children with acute lymphoblastic leukemia. Blood, The Journal of the American Society of Hematology 2002, 100, 1957-1964.

11. Aquino, V.M. Acute myelogenous leukemia. Curr Probl Pediatr Adolesc Health Care 2002, 32, 50-58, doi:10.1067/mps.2002.121791.

12. Zipf, T.; Berg, S.; Roberts, W.; Poplack, D.; Steuber, C.; Bleyer, W. Childhood leukemias. Clinical oncology. 2nd ed., New York: Churchill Livingstone 2000, 2402-2434.

13. Greaves, M.F.; Maia, A.T.; Wiemels, J.L.; Ford, A.M. Leukemia in twins: lessons in natural history. Blood 2003, 102, 23212333.

14. Stieglitz, E, Loh, ML;Genetic predispositions to childhood leukemia. Ther Adv Hematol 2013 4(4) 270-290, doi: 10.1177/ 2040620713498161

15. Swaminathan, M.; Bannon, S.A.; Routbort, M.; Naqvi, K.; Kadia, T.M.; Takahashi, K.; Alvarado, Y.; Ravandi-Kashani, F.; Patel, K.P.; Champlin, R., et al. Hematologic malignancies and Li-Fraumeni syndrome. Cold Spring Harb Mol Case Stud 2019, 5, doi:10.1101/mcs.a003210.

16. Robison, L.; Neglia, J. Epidemiology of Down syndrome and childhood acute leukemia. Progress in clinical and biological research 1987, 246, 19-32.

17. Woods, W.G.; Roloff, J.S.; Lukens, J.N.; Krivit, W. The occurrence of leukemia in patients with the Shwachman syndrome. The Journal of pediatrics 1981, 99, 425-428.

18. Shearer, P.; Parham, D.; Kovnar, E.; Kun, L.; Rao, B.; Lobe, T.; Pratt, C. Neurofibromatosis type I and malignancy: review of 32 pediatric cases treated at a single institution. Medical and pediatric oncology 1994, 22, 78-83.

19. Swift, M. Fanconi's anaemia in the genetics of neoplasia. Nature 1971, 230, 370-373.

20. Willis, A.E.; Lindahl, T. DNA ligase I deficiency in Bloom's syndrome. Nature 1987, 325, 355-357. 
21. Miller, R.W. Relation between cancer and congenital defects: an epidemiologic evaluation. Journal of the National Cancer Institute 1968, 40, 1079-1085.

22. Toledano, S.R.; Lange, B.J. Ataxia-telangiectasia and acute lymphoblastic leukemia. Cancer 1980, 45, 1675-1678.

23. Brown, W.C.; Doll, R.; Hill, A.B. Incidence of leukaemia after exposure to diagnostic radiation in utero. British medical journal 1960, 2, 1539.

24. Stewart, A.; Webb, J.; Giles, D.; Hewitt, D. Malignant disease in childhood and diagnostic irradiation in utero. The Lancet 1956, 268, 447 .

25. Kleinerman, R.A. Cancer risks following diagnostic and therapeutic radiation exposure in children. Pediatric radiology 2006, 36, 121-125.

26. Gardner, M.J. Review of reported increases of childhood cancer rates in the vicinity of nuclear installations in the UK. Journal of the Royal Statistical Society: Series A (Statistics in Society) 1989, 152, 307-325.

27. Meinert, R.; Kaletsch, U.; Kaatsch, P.; Schüz, J.; Michaelis, J. Associations between childhood cancer and ionizing radiation: results of a population-based case-control study in Germany. Cancer Epidemiology and Prevention Biomarkers 1999, 8, 793-799.

28. Finch, S.C. Radiation-induced leukemia: lessons from history. Best Practice E Research Clinical Haematology 2007, 20, 109118.

29. Bhatia, S.; Robison, L.L. Epidemiology of leukemia and lymphoma. Current Opinion in Hematology 1999, 6, 201.

30. Zeeb, H.; Blettner, M. Adult leukaemia: what is the role of currently known risk factors? Radiation and environmental biophysics 1998, 36, 217-228.

31. Sandler, D.P.; Ross, J.A. Epidemiology of acute leukemia in children and adults. In Proceedings of Seminars in oncology; pp. 3-16.

32. Sandler, D.P. Epidemiology and etiology of acute leukemia: an update. Leukemia 1992, 6 Suppl 4, 3-5.

33. Tsai RJ, Luckhaupt SE, Schumacher P, Cress RD, Deapen DM, Calvert GM. Acute myeloid leukemia risk by industry and occupation. Leuk Lymphoma. 2014;55(11):2584-2591. doi:10.3109/10428194.2014.894189

34. Burmeister, L.F.; Van Lier, S.F.; Isacson, P. Leukemia and farm practices in Iowa. Am J Epidemiol 1982, 115, 720-728, doi:10.1093/oxfordjournals.aje.a113354. 
35. Loomis, D.P.; Savitz, D.A. Occupation and leukemia mortality among men in 16 states: 1985-1987. Am J Ind Med 1991, 19, 509-521, doi:10.1002/ajim.4700190408.

36. Pearce, N.E.; Sheppard, R.A.; Howard, J.K.; Fraser, J.; Lilley, B.M. Leukemia among New Zealand agricultural workers. A cancer registry-based study. Am J Epidemiol 1986, 124, 402-409, doi:10.1093/oxfordjournals.aje.a114410.

37. Morton, W.; Marjanovic, D. Leukemia incidence by occupation in the Portland-Vancouver metropolitan area. Am J Ind Med 1984, 6, 185-205, doi:10.1002/ajim.4700060304.

38. Keller-Byrne, J.E.; Khuder, S.A.; Schaub, E.A. Meta-analysis of leukemia and farming. Environ Res 1995, 71, 1-10, doi:10.1006/enrs.1995.1060.

39. Blair, A.; Zheng, T.; Linos, A.; Stewart, P.A.; Zhang, Y.W.; Cantor, K.P. Occupation and leukemia: a population-based case-control study in Iowa and Minnesota. Am J Ind Med 2001, 40, 3-14, doi:10.1002/ajim.1066.

40. Adegoke, O.J.; Blair, A.; Shu, X.O.; Sanderson, M.; Jin, F.; Dosemeci, M.; Addy, C.L.; Zheng, W. Occupational history and exposure and the risk of adult leukemia in Shanghai. Ann Epidemiol 2003, 13, 485-494, doi:10.1016/s1047-2797(03)00037-1.

41. Descatha, A.; Jenabian, A.; Conso, F.; Ameille, J. Occupational exposures and haematological malignancies: overview on human recent data. Cancer Causes Control 2005, 16, 939-953, doi:10.1007/s10552-005-2301-3.

42. Brown, L.M.; Blair, A.; Gibson, R.; Everett, G.D.; Cantor, K.P.; Schuman, L.M.; Burmeister, L.F.; Van Lier, S.F.; Dick, F. Pesticide exposures and other agricultural risk factors for leukemia among men in Iowa and Minnesota. Cancer Res 1990, $50,6585-6591$.

43. Wong, O.; Harris, F.; Armstrong, T.W.; Hua, F. A hospital-based case-control study of acute myeloid leukemia in Shanghai: analysis of environmental and occupational risk factors by subtypes of the WHO classification. Chem Biol Interact 2010, 184, 112-128, doi:10.1016/j.cbi.2009.10.017.

44. Beane Freeman, L.E.; Deroos, A.J.; Koutros, S.; Blair, A.; Ward, M.H.; Alavanja, M.; Hoppin, J.A. Poultry and livestock exposure and cancer risk among farmers in the agricultural health study. Cancer Causes Control 2012, 23, 663-670, doi:10.1007/s10552-012-9921-1.

45. DiGiacomo, R.F.; Hopkins, S.G. Food animal and poultry retroviruses and human health. Vet Clin North Am Food Anim Pract 1997, 13, 177-190, doi:10.1016/s0749-0720(15)30371-6.

46. Aksoy, M. Malignancies due to occupational exposure to benzene. Am J Ind Med 1985, 7, 395-402, doi:10.1002/ajim.4700070506. 
47. Seniori Costantini, A.; Quinn, M.; Consonni, D.; Zappa, M. Exposure to benzene and risk of leukemia among shoe factory workers. Scand J Work Environ Health 2003, 29, 51-59, doi:10.5271/sjweh.704.

48. Raabe, G.K.; Collingwood, K.W.; Wong, O. An updated mortality study of workers at a petroleum refinery in Beaumont, Texas. Am J Ind Med 1998, 33, 61-81, doi:10.1002/(sici)1097-0274(199801)33:1<61::aid-ajim8>3.0.co;2-z.

49. Paci, E.; Buiatti, E.; Seniori Costantini, A.S.; Miligi, L.; Pucci, N.; Scarpelli, A.; Petrioli, G.; Simonato, L.; Winkelmann, R.; Kaldor, J.M. Aplastic anemia, leukemia and other cancer mortality in a cohort of shoe workers exposed to benzene. Scand J Work Environ Health 1989, 15, 313-318, doi:10.5271/sjweh.1845.

50. Terry, P.D.; Shore, D.L.; Rauscher, G.H.; Sandler, D.P. Occupation, hobbies, and acute leukemia in adults. Leuk Res 2005, 29, 1117-1130, doi:10.1016/j.leukres.2005.03.002.

51. Linet, M.S.; Malker, H.S.; McLaughlin, J.K.; Weiner, J.A.; Stone, B.J.; Blot, W.J.; Ericsson, J.L.; Fraumeni, J.F. Leukemias and occupation in Sweden: a registry-based analysis. Am J Ind Med 1988, 14, 319-330, doi:10.1002/ajim.4700140309.

52. Rinsky, R.A.; Smith, A.B.; Hornung, R.; Filloon, T.G.; Young, R.J.; Okun, A.H.; Landrigan, P.J. Benzene and leukemia. An epidemiologic risk assessment. N Engl J Med 1987, 316, 1044-1050, doi:10.1056/NEJM198704233161702.

53. Lindquist, R.; Nilsson, B.; Eklund, G.; Gahrton, G. Acute leukemia in professional drivers exposed to gasoline and diesel. Eur J Haematol 1991, 47, 98-103, doi:10.1111/j.1600-0609.1991.tb00129.x.

54. Enterline, P.E. Review of new evidence regarding the relationship of gasoline exposure to kidney cancer and leukemia. Environ Health Perspect 1993, 101 Suppl 6, 101-103, doi:10.1289/ehp.93101s6101.

55. Nilsson, R.; Nordlinder, R.; Järvholm, B. [Health risks of gasoline handling. Exposure to benzene can cause leukemia]. Lakartidningen 1993, 90, 1553-1557.

56. Wong, O.; Raabe, G.K. Cell-type-specific leukemia analyses in a combined cohort of more than 208,000 petroleum workers in the United States and the United Kingdom, 1937-1989. Regul Toxicol Pharmacol 1995, 21, 307-321, doi:10.1006/rtph.1995.1044.

57. Nordlinder, R.; Järvholm, B. Environmental exposure to gasoline and leukemia in children and young adults--an ecology study. Int Arch Occup Environ Health 1997, 70, 57-60, doi:10.1007/s004200050186.

58. Guénel, P.; Imbernon, E.; Chevalier, A.; Crinquand-Calastreng, A.; Goldberg, M. Leukemia in relation to occupational exposures to benzene and other agents: a case-control study nested in a cohort of gas and electric utility workers. Am J Ind Med 2002, 42, 87-97, doi:10.1002/ajim.10090. 
59. Glass, D.C.; Gray, C.N.; Jolley, D.J.; Gibbons, C.; Sim, M.R.; Fritschi, L.; Adams, G.G.; Bisby, J.A.; Manuell, R. Leukemia risk associated with low-level benzene exposure. Epidemiology 2003, 14, 569-577, doi:10.1097/01.ede.0000082001.05563.e0.

60. Schwartz, E. Proportionate mortality ratio analysis of automobile mechanics and gasoline service station workers in New Hampshire. Am J Ind Med 1987, 12, 91-99, doi:10.1002/ajim.4700120110.

61. Bethwaite, P.; Cook, A.; Kennedy, J.; Pearce, N. Acute leukemia in electrical workers: a New Zealand case-control study. Cancer Causes Control 2001, 12, 683-689, doi:10.1023/a:1011297803849.

62. Flodin, U.; Fredriksson, M.; Persson, B.; Hardell, L.; Axelson, O. Background radiation, electrical work, and some other exposures associated with acute myeloid leukemia in a case-referent study. Arch Environ Health 1986, 41, 77-84, doi:10.1080/00039896.1986.9937413.

63. Breysse, P.N.; Matanoski, G.M.; Elliott, E.A.; Francis, M.; Kaune, W.; Thomas, K. 60 Hertz magnetic field exposure assessment for an investigation of leukemia in telephone lineworkers. Am J Ind Med 1994, 26, 681-691, doi:10.1002/ajim.4700260510.

64. Matanoski, G.M.; Elliott, E.A.; Breysse, P.N.; Lynberg, M.C. Leukemia in telephone linemen. Am J Epidemiol 1993, 137, 609619, doi:10.1093/oxfordjournals.aje.a116718.

65. Kheifets, L.I.; London, S.J.; Peters, J.M. Leukemia risk and occupational electric field exposure in Los Angeles County, California. Am J Epidemiol 1997, 146, 87-90, doi:10.1093/oxfordjournals.aje.a009194.

66. Törnqvist, S.; Knave, B.; Ahlbom, A.; Persson, T. Incidence of leukaemia and brain tumours in some" electrical occupations". Occupational and Environmental Medicine 1991, 48, 597-603.

67. Carpenter, L.; Higgins, C.; Douglas, A.; Fraser, P.; Beral, V.; Smith, P. Combined analysis of mortality in three United Kingdom nuclear industry workforces, 1946-1988. Radiat Res 1994, 138, 224-238.

68. Omar, R.Z.; Barber, J.A.; Smith, P.G. Cancer mortality and morbidity among plutonium workers at the Sellafield plant of British Nuclear Fuels. Br J Cancer 1999, 79, 1288-1301, doi:10.1038/sj.bjc.6690207.

69. Preston, D.L.; Kato, H.; Kopecky, K.; Fujita, S. Studies of the mortality of A-bomb survivors. 8. Cancer mortality, 19501982. Radiat Res 1987, 111, 151-178.

70. Ritz, B.; Morgenstern, H.; Froines, J.; Young, B.B. Effects of exposure to external ionizing radiation on cancer mortality in nuclear workers monitored for radiation at Rocketdyne/Atomics International. Am J Ind Med 1999, 35, 21-31, doi:10.1002/(sici)1097-0274(199901)35:1<21::aid-ajim4>3.0.co;2-x. 
71. Shilnikova, N.S.; Preston, D.L.; Ron, E.; Gilbert, E.S.; Vassilenko, E.K.; Romanov, S.A.; Kuznetsova, I.S.; Sokolnikov, M.E.; Okatenko, P.V.; Kreslov, V.V., et al. Cancer mortality risk among workers at the Mayak nuclear complex. Radiat Res 2003, 159, 787-798, doi:10.1667/0033-7587(2003)159[0787:cmrawa]2.0.co;2.

72. Miller, B.A.; Blair, A.; Reed, E.J. Extended mortality follow-up among men and women in a U.S. furniture workers union. Am J Ind Med 1994, 25, 537-549, doi:10.1002/ajim.4700250408.

73. Skov, T.; Maarup, B.; Olsen, J.; Rørth, M.; Winthereik, H.; Lynge, E. Leukaemia and reproductive outcome among nurses handling antineoplastic drugs. Br J Ind Med 1992, 49, 855-861, doi:10.1136/oem.49.12.855.

74. Lie, J.A.; Kjaerheim, K. Cancer risk among female nurses: a literature review. Eur J Cancer Prev 2003, 12, 517-526, doi:10.1097/00008469-200312000-00011.

75. Petralia, S.A.; Dosemeci, M.; Adams, E.E.; Zahm, S.H. Cancer mortality among women employed in health care occupations in 24 U.S. states, 1984-1993. Am J Ind Med 1999, 36, 159-165, doi:10.1002/(sici)1097-0274(199907)36:1<159::aidajim23>3.0.co;2-k.

76. Mele, A.; Szklo, M.; Visani, G.; Stazi, M.A.; Castelli, G.; Pasquini, P.; Mandelli, F. Hair dye use and other risk factors for leukemia and pre-leukemia: a case-control study. Italian Leukemia Study Group. Am J Epidemiol 1994, 139, 609-619, doi:10.1093/oxfordjournals.aje.a117050.

77. Morgan, R.W.; Claxton, K.W.; Kaplan, S.D.; Parsons, J.M.; Wong, O. Mortality of paint and coatings industry workers. A follow-up study. J Occup Med 1985, 27, 377-378, doi:10.1097/00043764-198505000-00019.

78. Miller, B.A.; Silverman, D.T.; Hoover, R.N.; Blair, A. Cancer risk among artistic painters. Am J Ind Med 1986, 9, 281-287, doi:10.1002/ajim.4700090311.

79. Lindquist, R.; Nilsson, B.; Eklund, G.; Gahrton, G. Increased risk of developing acute leukemia after employment as a painter. Cancer 1987, 60, 1378-1384, doi:10.1002/1097-0142(19870915)60:6<1378::aid-cncr2820600636>3.0.co;2-d.

80. Chen, R.; Seaton, A. A meta-analysis of painting exposure and cancer mortality. Cancer Detect Prev 1998, 22, 533-539, doi:10.1046/j.1525-1500.1998.00a47.x.

81. Blair, A.; Decoufle, P.; Grauman, D. Causes of death among laundry and dry cleaning workers. Am J Public Health 1979, 69, 508-511, doi:10.2105/ajph.69.5.508.

82. McLean, D.; Mannetje, A.; Dryson, E.; Walls, C.; McKenzie, F.; Maule, M.; Cheng, S.; Cunningham, C.; Kromhout, H.; Boffetta, P., et al. Leukaemia and occupation: a New Zealand Cancer Registry-based case-control Study. Int J Epidemiol 2009, 38, 594-606, doi:10.1093/ije/dyn220. 
83. Forand, S.P. Leukaemia incidence among workers in the shoe and boot manufacturing industry: a case-control study. Environ Health 2004, 3, 7, doi:10.1186/1476-069X-3-7.

84. Floderus, B.; Törnqvist, S.; Stenlund, C. Incidence of selected cancers in Swedish railway workers, 1961-79. Cancer Causes Control 1994, 5, 189-194, doi:10.1007/BF01830265.

85. Alfredsson, L.; Hammar, N.; Karlehagen, S. Cancer incidence among male railway engine-drivers and conductors in Sweden, 1976-90. Cancer Causes Control 1996, 7, 377-381, doi:10.1007/BF00052944.

86. Appelbaum, F.A.m.l.i.a.I.A.M., Armitage JO, Nierderhuber JE, et al., editors. Abeloff's Clinical Oncology. 4th ed. Churchill Livingstone; Philadelphia, PA: 2008. pp. 2215-2234. .

87. Goldstein, B.D. Hematological and toxicological evaluation of formaldehyde as a potential cause of human leukemia. Hum Exp Toxicol 2011, 30, 725-735, doi:10.1177/0960327110381682.

88. O'Brien, T.R.; Decouflé, P. Cancer mortality among northern Georgia carpet and textile workers. Am J Ind Med 1988, 14, 1524, doi:10.1002/ajim.4700140104.

89. Kim, E.A.; Lee, H.E.; Ryu, H.W.; Park, S.H.; Kang, S.K. Cases series of malignant lymphohematopoietic disorder in korean semiconductor industry. Saf Health Work 2011, 2, 122-134, doi:10.5491/SHAW.2011.2.2.122.

90. Belson, M.; Kingsley, B.; Holmes, A. Risk factors for acute leukemia in children: a review. Environ Health Perspect 2007, 115, 138-145, doi:10.1289/ehp.9023.

91. Freedman, D.M.; Stewart, P.; Kleinerman, R.A.; Wacholder, S.; Hatch, E.E.; Tarone, R.E.; Robison, L.L.; Linet, M.S. Household solvent exposures and childhood acute lymphoblastic leukemia. Am J Public Health 2001, 91, 564-567, doi:10.2105/ajph.91.4.564.

92. Lowengart, R.A.; Peters, J.M.; Cicioni, C.; Buckley, J.; Bernstein, L.; Preston-Martin, S.; Rappaport, E. Childhood leukemia and parents' occupational and home exposures. J Natl Cancer Inst 1987, 79, 39-46.

93. Buckley, J.D.; Robison, L.L.; Swotinsky, R.; Garabrant, D.H.; LeBeau, M.; Manchester, P.; Nesbit, M.E.; Odom, L.; Peters, J.M.; Woods, W.G. Occupational exposures of parents of children with acute nonlymphocytic leukemia: a report from the Childrens Cancer Study Group. Cancer Res 1989, 49, 4030-4037.

94. Rinsky, R.A.; Young, R.J.; Smith, A.B. Leukemia in benzene workers. Am J Ind Med 1981, 2, 217-245, doi:10.1002/ajim.4700020305.

95. Miller, R.W. Persons with exceptionally high risk of leukemia. Cancer Res 1967, 27, 2420-2423. 
96. MOLONEY, W.C. Leukemia in survivors of atomic bombing. N Engl J Med 1955, 253, 88-90, doi:10.1056/NEJM195507212530302.

97. Sali, D.; Cardis, E.; Sztanyik, L.; Auvinen, A.; Bairakova, A.; Dontas, N.; Grosche, B.; Kerekes, A.; Kusic, Z.; Kusoglu, C., et al. Cancer consequences of the Chernobyl accident in Europe outside the former USSR: a review. Int J Cancer 1996, 67, 343352, doi:10.1002/(SICI)1097-0215(19960729)67:3<343::AID-IJC7>3.0.CO;2-R.

98. Ron, E. Ionizing radiation and cancer risk: evidence from epidemiology. Radiat Res 1998, 150, S30-41.

99. Mahoney, M.C.; Moysich, K.B.; McCarthy, P.L.; McDonald, R.C.; Stepanenko, V.F.; Day, R.W.; Michalek, A.M. The Chernobyl childhood leukemia study: background \& lessons learned. Environ Health 2004, 3, 12, doi:10.1186/1476-069X-312.

100. Shu, X.O.; Reaman, G.H.; Lampkin, B.; Sather, H.N.; Pendergrass, T.W.; Robison, L.L. Association of paternal diagnostic Xray exposure with risk of infant leukemia. Investigators of the Childrens Cancer Group. Cancer Epidemiol Biomarkers Prev 1994, 3, 645-653.

101. Shu, X.O.; Potter, J.D.; Linet, M.S.; Severson, R.K.; Han, D.; Kersey, J.H.; Neglia, J.P.; Trigg, M.E.; Robison, L.L. Diagnostic $\mathrm{X}$-rays and ultrasound exposure and risk of childhood acute lymphoblastic leukemia by immunophenotype. Cancer Epidemiol Biomarkers Prev 2002, 11, 177-185.

102. Bailey, H.D.; Armstrong, B.K.; de Klerk, N.H.; Fritschi, L.; Attia, J.; Lockwood, L.; Milne, E.; Consortium, A.-A. Exposure to diagnostic radiological procedures and the risk of childhood acute lymphoblastic leukemia. Cancer Epidemiol Biomarkers Prev 2010, 19, 2897-2909, doi:10.1158/1055-9965.EPI-10-0542.

103. Boice, J.D.; Morin, M.M.; Glass, A.G.; Friedman, G.D.; Stovall, M.; Hoover, R.N.; Fraumeni, J.F. Diagnostic x-ray procedures and risk of leukemia, lymphoma, and multiple myeloma. JAMA 1991, 265, 1290-1294.

104. Nikkilä A, Raitanen J, Lohi O, Auvinen A. Radiation exposure from computerized tomography and risk of childhood leukemia: Finnish register-based case-control study of childhood leukemia (FRECCLE). Haematologica. 2020,105(3):849-850.

105. Infante-Rivard, C.; Deadman, J.E. Maternal occupational exposure to extremely low frequency magnetic fields during pregnancy and childhood leukemia. Epidemiology 2003, 14, 437-441, doi:10.1097/01.ede.0000078421.60231.bc.

106. Ahlbom, A.; Day, N.; Feychting, M.; Roman, E.; Skinner, J.; Dockerty, J.; Linet, M.; McBride, M.; Michaelis, J.; Olsen, J.H., et al. A pooled analysis of magnetic fields and childhood leukaemia. Br J Cancer 2000, 83, 692-698, doi:10.1054/bjoc.2000.1376. 
107. Savitz, D.A.; Chen, J.H. Parental occupation and childhood cancer: review of epidemiologic studies. Environ Health Perspect 1990, 88, 325-337, doi:10.1289/ehp.9088325.

108. Kleiner man, R.A.; Kaune, W.T.; Hatch, E.E.; Wacholder, S.; Linet, M.S.; Robison, L.L.; Niwa, S.; Tarone, R.E. Are children living near high-voltage power lines at increased risk of acute lymphoblastic leukemia? Am J Epidemiol 2000, 151, 512-515, doi:10.1093/oxfordjournals.aje.a010237.

109. Linet, M.S.; Hatch, E.E.; Kleinerman, R.A.; Robison, L.L.; Kaune, W.T.; Friedman, D.R.; Severson, R.K.; Haines, C.M.; Hartsock, C.T.; Niwa, S., et al. Residential exposure to magnetic fields and acute lymphoblastic leukemia in children. $N$ Engl J Med 1997, 337, 1-7, doi:10.1056/NEJM199707033370101.

110. Myers, A.; Clayden, A.D.; Cartwright, R.A.; Cartwright, S.C. Childhood cancer and overhead powerlines: a case-control study. Br J Cancer 1990, 62, 1008-1014, doi:10.1038/bjc.1990.428.

111. Morice, PM, Leary, A, Dolladille, C, chretien, B, Poulain, L, Gonzalez-Martin, A, Moore, K, O’Reilly, EM, Ray-Coquard, I, Alexandre, J. Myelodysplastic syndrome and acute myeloid leukaemia in patients treated with PARP inhibitors: A safety meta-analysis of randomized controlled trials and a retrospective study of the WHO pharmacovigilance database. Lancet Haematol 2021; 8(2) E122-E134.

112. Tebbi, C.K.; London, W.B.; Friedman, D.; Villaluna, D.; De Alarcon, P.A.; Constine, L.S.; Mendenhall, N.P.; Sposto, R.; Chauvenet, A.; Schwartz, C.L. Dexrazoxane-associated risk for acute myeloid leukemia/myelodysplastic syndrome and other secondary malignancies in pediatric Hodgkin's disease. J Clin Oncol 2007, 25, 493-500, doi:10.1200/JCO.2005.02.3879.

113. Curtis, RE, Boice, JD, Stovall, M, Bernstein, L, Greenberg, RS, Flannery, JT, Schwartz, AG, Weyer, P, Moloney, W, Hoover, RN. Risk of Leukemia after Chemotherapy and Radiation Treatment for Breast Cancer. N Engl J Med 1992, 326:1745-1751. doi10.1056/NEJM199206253262605

114. Rushton, L.; Romaniuk, H. A case-control study to investigate the risk of leukaemia associated with exposure to benzene in petroleum marketing and distribution workers in the United Kingdom. Occup Environ Med 1997, 54, 152-166, doi:10.1136/oem.54.3.152.

115. Shu, X.O.; Stewart, P.; Wen, W.Q.; Han, D.; Potter, J.D.; Buckley, J.D.; Heineman, E.; Robison, L.L. Parental occupational exposure to hydrocarbons and risk of acute lymphocytic leukemia in offspring. Cancer Epidemiol Biomarkers Prev 1999, 8 , 783-791.

116. Zahm, S.H.; Ward, M.H. Pesticides and childhood cancer. Environ Health Perspect 1998, 106 Suppl 3, 893-908, doi:10.1289/ehp.98106893.

117. Grossman, J. What's hiding under the sink: dangers of household pesticides. Environ Health Perspect 1995, 103, 550-554, doi:10.1289/ehp.95103550. 
118. Daniels, J.L.; Olshan, A.F.; Savitz, D.A. Pesticides and childhood cancers. Environ Health Perspect 1997, 105, 1068-1077, doi:10.1289/ehp.971051068.

119. Infante-Rivard, C.; Labuda, D.; Krajinovic, M.; Sinnett, D. Risk of childhood leukemia associated with exposure to pesticides and with gene polymorphisms. Epidemiology 1999, 481-487.

120. Menegaux, F.; Baruchel, A.; Bertrand, Y.; Lescoeur, B.; Leverger, G.; Nelken, B.; Sommelet, D.; Hémon, D.; Clavel, J. Household exposure to pesticides and risk of childhood acute leukaemia. Occup Environ Med 2006, 63, 131-134, doi:10.1136/oem.2005.023036.

121. Knox, E. Childhood cancers and atmospheric carcinogens. Journal of Epidemiology E Community Health 2005, 59, 101-105.

122. Brondum, J.; Shu, X.O.; Steinbuch, M.; Severson, R.K.; Potter, J.D.; Robison, L.L. Parental cigarette smoking and the risk of acute leukemia in children. Cancer 1999, 85, 1380-1388.

123. Sorahan, T.; Lancashire, R.; Prior, P.; Peck, I.; Stewart, A. Childhood cancer and parental use of alcohol and tobacco. Ann Epidemiol 1995, 5, 354-359, doi:10.1016/1047-2797(95)00032-3.

124. Ji, B.T.; Shu, X.O.; Linet, M.S.; Zheng, W.; Wacholder, S.; Gao, Y.T.; Ying, D.M.; Jin, F. Paternal cigarette smoking and the risk of childhood cancer among offspring of nonsmoking mothers. J Natl Cancer Inst 1997, 89, 238-244, doi:10.1093/jnci/89.3.238.

125. Stjernfeldt, M.; Ludvigsson, J.; Berglund, K.; Lindsten, J. Maternal smoking during pregnancy and the risk of childhood cancer. Lancet 1986, 2, 687-688, doi:10.1016/s0140-6736(86)90194-7.

126. John, E.M.; Savitz, D.A.; Sandler, D.P. Prenatal exposure to parents' smoking and childhood cancer. Am J Epidemiol 1991, 133, 123-132, doi:10.1093/oxfordjournals.aje.a115851.

127. Sorahan, T.; Prior, P.; Lancashire, R.J.; Faux, S.P.; Hultén, M.A.; Peck, I.M.; Stewart, A.M. Childhood cancer and parental use of tobacco: deaths from 1971 to 1976. Br J Cancer 1997, 76, 1525-1531, doi:10.1038/bjc.1997.589.

128. Shu, X.O.; Ross, J.A.; Pendergrass, T.W.; Reaman, G.H.; Lampkin, B.; Robison, L.L. Parental alcohol consumption, cigarette smoking, and risk of infant leukemia: a Childrens Cancer Group study. J Natl Cancer Inst 1996, 88, 24-31, doi:10.1093/jnci/88.1.24.

129. Pang, D.; McNally, R.; Birch, J.M. Parental smoking and childhood cancer: results from the United Kingdom Childhood Cancer Study. Br J Cancer 2003, 88, 373-381, doi:10.1038/sj.bjc.6600774. 
130. Robison, L.L.; Buckley, J.D.; Daigle, A.E.; Wells, R.; Benjamin, D.; Arthur, D.C.; Hammond, G.D. Maternal drug use and risk of childhood nonlymphoblastic leukemia among offspring. An epidemiologic investigation implicating marijuana (a report from the Childrens Cancer Study Group). Cancer 1989, 63, 1904-1911.

131. Dockerty, J.D.; Draper, G.; Vincent, T.; Rowan, S.D.; Bunch, K.J. Case-control study of parental age, parity and socioeconomic level in relation to childhood cancers. International journal of epidemiology 2001, 30, 1428-1437.

132. Kaye, S.A.; Robison, L.L.; Smithson, W.A.; Gunderson, P.; King, F.L.; Neglia, J.P. Maternal reproductive history and birth characteristics in childhood acute lymphoblastic leukemia. Cancer 1991, 68, 1351-1355, doi:10.1002/1097-

0142(19910915)68:6<1351::aid-cncr2820680627>3.0.co;2-j.

133. Ross, J.A.; Davies, S.M.; Potter, J.D.; Robison, L.L. Epidemiology of childhood leukemia, with a focus on infants. Epidemiol Rev 1994, 16, 243-272, doi:10.1093/oxfordjournals.epirev.a036153.

134. Yeazel, M.W.; Buckley, J.D.; Woods, W.G.; Ruccione, K.; Robison, L.L. History of maternal fetal loss and increased risk of childhood acute leukemia at an early age. A report from the Childrens Cancer Group. Cancer 1995, 75, 1718-1727, doi:10.1002/1097-0142(19950401)75:7<1718::aid-cncr2820750725>3.0.co;2-g.

135. Westergaard, T.; Andersen, P.K.; Pedersen, J.B.; Olsen, J.H.; Frisch, M.; Sørensen, H.T.; Wohlfahrt, J.; Melbye, M. Birth characteristics, sibling patterns, and acute leukemia risk in childhood: a population-based cohort study. J Natl Cancer Inst 1997, 89, 939-947, doi:10.1093/jnci/89.13.939.

136. Smith, M. Considerations on a possible viral etiology for B-precursor acute lymphoblastic leukemia of childhood. Journal of immunotherapy 1997, 20, 89-100.

137. Wiemels, J. Perspectives on the causes of childhood leukemia. Chem Biol Interact 2012, 196, 59-67, doi:10.1016/j.cbi.2012.01.007.

138. Tebbi, C.K.; Badiga, A.; Sahakian, E.; Arora, A.I.; Nair, S.; Powers, J.J.; Achille, A.N.; Jaglal, M.V.; Patel, S.; Migone, F. Plasma of Acute Lymphoblastic Leukemia Patients React to the Culture of a Mycovirus Containing Aspergillus flavus. $J$ Pediatr Hematol Oncol 2020, 42, 350-358, doi:10.1097/MPH.0000000000001845.

139. Tebbi, C.K.; Badiga, A.; Sahakian, E.; Powers, J.J.; Achille, A.N.; Patel, S.; Migone, F. Exposure to a mycovirus containing Aspergillus Flavus reproduces acute lymphoblastic leukemia cell surface and genetic markers in cells from patients in remission and not controls. Cancer Treat Res Commun 2020, 26, 100279, doi:10.1016/j.ctarc.2020.100279.

140. Greaves, M.F. Speculations on the cause of childhood acute lymphoblastic leukemia. Leukemia 1988, 2, 120-125. 
141. Gold, J.E.; Castella, A.; Zalusky, R. B-cell acute lymphocytic leukemia in HIV-antibody-positive patients. American journal of hematology 1989, 32, 200-204.

142. Pantanowitz, L.; Schlecht, H.P.; Dezube, B.J. The growing problem of non-AIDS-defining malignancies in HIV. Curr Opin Oncol 2006, 18, 469-478, doi:10.1097/01.cco.0000239886.13537.ed.

143. Lehtinen, M.; Koskela, P.; Ogmundsdottir, H.M.; Bloigu, A.; Dillner, J.; Gudnadottir, M.; Hakulinen, T.; Kjartansdottir, A.; Kvarnung, M.; Pukkala, E., et al. Maternal herpesvirus infections and risk of acute lymphoblastic leukemia in the offspring. Am J Epidemiol 2003, 158, 207-213, doi:10.1093/aje/kwg137.

144. Bartenhagen, C.; Fischer, U.; Korn, K.; Pfister, S.M.; Gombert, M.; Chen, C.; Okpanyi, V.; Hauer, J.; Rinaldi, A.; Bourquin, J.P., et al. Infection as a cause of childhood leukemia: virus detection employing whole genome sequencing. Haematologica 2017, 102, e179-e183, doi:10.3324/haematol.2016.155382.

145. Martín-Lorenzo, A.; Hauer, J.; Vicente-Dueñas, C.; Auer, F.; González-Herrero, I.; García-Ramírez, I.; Ginzel, S.; Thiele, R.; Constantinescu, S.N.; Bartenhagen, C., et al. Infection Exposure is a Causal Factor in B-cell Precursor Acute Lymphoblastic Leukemia as a Result of Pax5-Inherited Susceptibility. Cancer Discov 2015, 5, 1328-1343, doi:10.1158/2159-8290.CD-15-0892.

146. Rowe, M.; Fitzsimmons, L.; Bell, A.I. Epstein-Barr virus and Burkitt lymphoma. Chin J Cancer 2014, 33, 609-619, doi:10.5732/cjc.014.10190.

147. Li, C.; Zee, B.; Lee, J.; Chik, K.; Ha, S.; Lee, V. Impact of SARS on development of childhood acute lymphoblastic leukaemia. Leukemia 2007, 21, 1353-1356.

148. Taub, J.W.; Ge, Y.; Xavier, A.C. COVID-19 and childhood acute lymphoblastic leukemia. Pediatric Blood E Cancer 2020.

149. Greaves, M. COVID-19 and childhood acute lymphoblastic leukemia. Pediatric Blood \& Cancer 2020, 67, e28481.

150. Maia, R.a.R.; Wünsch Filho, V. Infection and childhood leukemia: review of evidence. Rev Saude Publica 2013, 47, 11721185, doi:10.1590/s0034-8910.2013047004753.

151. Chabay, P.A.; Preciado, M.V. EBV primary infection in childhood and its relation to B-cell lymphoma development: a mini-review from a developing region. Int J Cancer 2013, 133, 1286-1292, doi:10.1002/ijc.27858.

152. Matsuoka, M. Human T-cell leukemia virus type I and adult T-cell leukemia. Oncogene 2003, 22, 5131-5140, doi:10.1038/sj.onc.1206551.

153. Hauer, J.; Martín-Lorenzo, A.; Sánchez-García, I. Infection causes childhood leukemia. Aging (Albany NY) 2015, 7, 607-608, doi:10.18632/aging.100815. 
154. Wray, B.B.; O'Steen, K.G. Mycotoxin-producing fungi from house associated with leukemia. Arch Environ Health 1975, 30, 571-573, doi:10.1080/00039896.1975.10666781.

155. Wray, B.B.; Harmon, C.A.; Rushing, E.J.; Cole, R.J. Precipitins to an aflatoxin-producing strain of Aspergillus flavus in patients with malignancy. Journal of Cancer Research and Clinical Oncology 1982, 103, 181-185.

156. McPhedran, P.; Heath, C.W. Multiple cases of leukemia associated with one house. JAMA 1969, $209,2021-2025$.

157. Wray, B.B.; Rushing, E.J.; Boyd, R.C.; Schindel, A.M. Suppression of phytohemagglutinin response by fungi from a "leukemia" house. Arch Environ Health 1979, 34, 350-353, doi:10.1080/00039896.1979.10667430.

158. Hisano, S.; Zhang, R.; Faruk, M.I.; Kondo, H.; Suzuki, N. A neo-virus lifestyle exhibited by a (+)ssRNA virus hosted in an unrelated dsRNA virus: Taxonomic and evolutionary considerations. Virus Res 2018, 244, 75-83, doi:10.1016/j.virusres.2017.11.006.

159. Schmidt, F.R. The RNA interference-virus interplay: tools of nature for gene modulation, morphogenesis, evolution and a possible mean for aflatoxin control. Appl Microbiol Biotechnol 2009, 83, 611-615, doi:10.1007/s00253-009-2007-7.

160. Kotta-Loizou, I.; Coutts, R.H.A. Mycoviruses in. Front Microbiol 2017, 8, 1699, doi:10.3389/fmicb.2017.01699.

161. Pitt, J.I. Toxigenic fungi: which are important? Med Mycol 2000, 38 Suppl 1, 17-22.

162. Klein, K.R.; Woodward, C.S.; Waller, E.K.; Lechowicz, M.J.; Rosenthal, H. Effects of Mycotoxins on Mononuclear Cells (MNCs) in Normal Blood, T-Cell Leukemia and Lymphoma Cell Lines. American Society of Hematology: 2005.

163. Konstantinovas, C.; de Oliveira Mendes, T.A.; Vannier-Santos, M.A.; Lima-Santos, J. Modulation of Human Immune Response by Fungal Biocontrol Agents. Front Microbiol 2017, 8, 39, doi:10.3389/fmicb.2017.00039.

164. Pahl, H.L.; Krauss, B.; Schulze-Osthoff, K.; Decker, T.; Traenckner, E.B.; Vogt, M.; Myers, C.; Parks, T.; Warring, P.; Mühlbacher, A., et al. The immunosuppressive fungal metabolite gliotoxin specifically inhibits transcription factor NFkappaB. J Exp Med 1996, 183, 1829-1840, doi:10.1084/jem.183.4.1829.

165. Kordes, U.; Krappmann, D.; Heissmeyer, V.; Ludwig, W.D.; Scheidereit, C. Transcription factor NF-kappaB is constitutively activated in acute lymphoblastic leukemia cells. Leukemia 2000, 14, 399-402, doi:10.1038/sj.leu.2401705.

166. Reilly, J.T. Pathogenesis of acute myeloid leukaemia and inv(16)(p13;q22): a paradigm for understanding leukaemogenesis? Br J Haematol 2005, 128, 18-34, doi:10.1111/j.1365-2141.2004.05236.x. 
167. Greaves, M. Author Correction: A causal mechanism for childhood acute lymphoblastic leukaemia. Nat Rev Cancer 2018, 18, 526, doi:10.1038/s41568-018-0029-0.

168. Ries LAG, M.D., Krapcho M, Mariotto A, Miller BA, Feuer EJ, Clegg L, Horner MJ, Howlader N, Eisner MP, Reichman M, Edwards BK (eds). SEER Cancer Statistics Review, 1975-2004, National Cancer Institute. Bethesda, MD,

https://seer.cancer.gov/csr/1975 2004/, based on November 2006 SEER data submission, posted to the SEER web site, 2007. Availabe online: (accessed on

169. Puumala, S.E.; Ross, J.A.; Aplenc, R.; Spector, L.G. Epidemiology of childhood acute myeloid leukemia. Pediatr Blood Cancer 2013, 60, 728-733, doi:10.1002/pbc.24464.

170. Xie, Y.; Davies, S.M.; Xiang, Y.; Robison, L.L.; Ross, J.A. Trends in leukemia incidence and survival in the United States (1973-1998). Cancer 2003, 97, 2229-2235, doi:10.1002/cncr.11316.

171. Fong, C.T.; Brodeur, G.M. Down's syndrome and leukemia: epidemiology, genetics, cytogenetics and mechanisms of leukemogenesis. Cancer Genet Cytogenet 1987, 28, 55-76, doi:10.1016/0165-4608(87)90354-2.

172. Khan, I.; Malinge, S.; Crispino, J. Myeloid leukemia in Down syndrome. Crit Rev Oncog 2011, 16, 25-36, doi:10.1615/critrevoncog.v16.i1-2.40.

173. Lagunas-Rangel, F.A.; Chávez-Valencia, V.; Gómez-Guijosa, M.; Cortes-Penagos, C. Acute Myeloid Leukemia-Genetic Alterations and Their Clinical Prognosis. Int J Hematol Oncol Stem Cell Res 2017, 11, 328-339.

174. Heim, S.; Mitelman, F. Cytogenetic analysis in the diagnosis of acute leukemia. Cancer 1992, 70, 1701-1709, doi:10.1002/1097-0142(19920915)70:4+<1701::aid-cncr2820701609>3.0.co;2-s.

175. Khwaja, A.; Bjorkholm, M.; Gale, R.E.; Levine, R.L.; Jordan, C.T.; Ehninger, G.; Bloomfield, C.D.; Estey, E.; Burnett, A.; Cornelissen, J.J., et al. Acute myeloid leukaemia. Nat Rev Dis Primers 2016, 2, 16010, doi:10.1038/nrdp.2016.10.

176. Moorman, A.V.; Roman, E.; Willett, E.V.; Dovey, G.J.; Cartwright, R.A.; Morgan, G.J. Karyotype and age in acute myeloid leukemia. Are they linked? Cancer Genet Cytogenet 2001, 126, 155-161, doi:10.1016/s0165-4608(00)00414-3.

177. Bloomfield, C.D.; Lawrence, D.; Byrd, J.C.; Carroll, A.; Pettenati, M.J.; Tantravahi, R.; Patil, S.R.; Davey, F.R.; Berg, D.T.; Schiffer, C.A., et al. Frequency of prolonged remission duration after high-dose cytarabine intensification in acute myeloid leukemia varies by cytogenetic subtype. Cancer Res 1998, 58, 4173-4179.

178. Grimwade, D.; Walker, H.; Oliver, F.; Wheatley, K.; Harrison, C.; Harrison, G.; Rees, J.; Hann, I.; Stevens, R.; Burnett, A., et al. The importance of diagnostic cytogenetics on outcome in AML: analysis of 1,612 patients entered into the MRC AML 10 trial. The Medical Research Council Adult and Children's Leukaemia Working Parties. Blood 1998, 92, $2322-2333$. 
179. Mauritzson, N.; Johansson, B.; Albin, M.; Billström, R.; Ahlgren, T.; Mikoczy, Z.; Nilsson, P.G.; Hagmar, L.; Mitelman, F. A single-center population-based consecutive series of 1500 cytogenetically investigated adult hematological malignancies: karyotypic features in relation to morphology, age and gender. Eur J Haematol 1999, 62, 95-102, doi:10.1111/j.16000609.1999.tb01728.x.

180. Rossi, G.; Pelizzari, A.M.; Bellotti, D.; Tonelli, M.; Barlati, S. Cytogenetic analogy between myelodysplastic syndrome and acute myeloid leukemia of elderly patients. Leukemia 2000, 14, 636-641, doi:10.1038/sj.leu.2401711.

181. Bacher, U.; Schnittger, S.; Haferlach, T. Molecular genetics in acute myeloid leukemia. Curr Opin Oncol 2010, 22, 646-655, doi:10.1097/CCO.0b013e32833ed806.

182. Abe, R.; Raza, A.; Preisler, H.D.; Tebbi, C.K.; Sandberg, A.A. Chromosomes and causation of human cancer and leukemia. LIV. Near-tetraploidy in acute leukemia. Cancer Genet Cytogenet 1985, 14, 45-59, doi:10.1016/0165-4608(85)90214-6.

183. Andersen, M.K.; Christiansen, D.H.; Jensen, B.A.; Ernst, P.; Hauge, G.; Pedersen-Bjergaard, J. Therapy-related acute lymphoblastic leukaemia with MLL rearrangements following DNA topoisomerase II inhibitors, an increasing problem: report on two new cases and review of the literature since 1992. Br J Haematol 2001, 114, 539-543, doi:10.1046/j.13652141.2001.03000.x.

184. Larson, R.A.; Wang, Y.; Banerjee, M.; Wiemels, J.; Hartford, C.; Le Beau, M.M.; Smith, M.T. Prevalence of the inactivating 609C--> T polymorphism in the $\mathrm{NAD}(\mathrm{P}) \mathrm{H}$ :quinone oxidoreductase (NQO1) gene in patients with primary and therapyrelated myeloid leukemia. Blood 1999, 94, 803-807.

185. Smith, M.T.; Wang, Y.; Kane, E.; Rollinson, S.; Wiemels, J.L.; Roman, E.; Roddam, P.; Cartwright, R.; Morgan, G. Low $\mathrm{NAD}(\mathrm{P}) \mathrm{H}$ :quinone oxidoreductase 1 activity is associated with increased risk of acute leukemia in adults. Blood 2001,97, 1422-1426, doi:10.1182/blood.v97.5.1422.

186. Gurney, J.G.; Severson, R.K.; Davis, S.; Robison, L.L. Incidence of cancer in children in the United States. Sex-, race-, and 1year age-specific rates by histologic type. Cancer 1995, 75, 2186-2195, doi:10.1002/1097-0142(19950415)75:8<2186::aidcncr2820750825>3.0.co;2-f.

187. Clarkson, B.D.; Boyse, E.A. Possible explanation of the high concoddance for acute leukaemia in monozygotic twins. Lancet 1971, 1, 699-701, doi:10.1016/s0140-6736(71)92705-x.

188. Greaves, M.F.; Maia, A.T.; Wiemels, J.L.; Ford, A.M. Leukemia in twins: lessons in natural history. Blood 2003, 102, 23212333, doi:10.1182/blood-2002-12-3817.

189. HEATH, C.W.; MOLONEY, W.C. FAMILIAL LEUKEMIA; FIVE CASES OF ACUTE LEUKEMIA IN THREE GENERATIONS. N Engl J Med 1965, 272, 882-887, doi:10.1056/NEJM196504292721703. 
190. Draper, G.J.; Heaf, M.M.; Kinnier Wilson, L.M. Occurrence of childhood cancers among sibs and estimation of familial risks. J Med Genet 1977, 14, 81-90, doi:10.1136/jmg.14.2.81.

191. Pui, C.H.; Nichols, K.E.; Yang, J.J. Somatic and germline genomics in paediatric acute lymphoblastic leukaemia. Nat Rev Clin Oncol 2019, 16, 227-240, doi:10.1038/s41571-018-0136-6.

192. Gu, Z.; Churchman, M.L.; Roberts, K.G.; Moore, I.; Zhou, X.; Nakitandwe, J.; Hagiwara, K.; Pelletier, S.; Gingras, S.; Berns, H., et al. PAX5-driven subtypes of B-progenitor acute lymphoblastic leukemia. Nat Genet 2019, 51, 296-307, doi:10.1038/s41588-018-0315-5.

193. Raboso-Gallego, J.; Casado-García, A.; Isidro-Hernández, M.; Vicente-Dueñas, C. Epigenetic Priming in Childhood Acute Lymphoblastic Leukemia. Front Cell Dev Biol 2019, 7, 137, doi:10.3389/fcell.2019.00137.

194. Schmiegelow, K.; Vestergaard, T.; Nielsen, S.M.; Hjalgrim, H. Etiology of common childhood acute lymphoblastic leukemia: the adrenal hypothesis. Leukemia 2008, 22, 2137-2141, doi:10.1038/leu.2008.212. 